University of Wollongong

Research Online

Faculty of Engineering and Information

Faculty of Engineering and Information

Sciences - Papers: Part A

Sciences

January 2016

Experimental investigations on circular concrete columns reinforced with GFRP bars and helices under different loading conditions

Muhammad N. S Hadi

University of Wollongong, mhadi@uow.edu.au

Hogr Karim

University of Wollongong, hmjkk643@uowmail.edu.au

M Neaz Sheikh

University of Wollongong, msheikh@uow.edu.au

Follow this and additional works at: https://ro.uow.edu.au/eispapers

Research Online is the open access institutional repository for the University of Wollongong. For further information contact the UOW Library: research-pubs@uow.edu.au 


\title{
Experimental investigations on circular concrete columns reinforced with GFRP bars and helices under different loading conditions
}

\author{
Abstract \\ Glass-fiber-reinforced polymer (GFRP) bar has emerged as a preferable alternative to steel bar in \\ reinforced concrete (RC) members in harsh, corrosive, coastal environments in order to eliminate \\ corrosion problems. However, only limited experimental studies are available on the performance and \\ behavior of concrete columns reinforced with GFRP bars under different loading conditions. This study \\ investigates the use of GFRP bars and GFRP helices (spirals) as longitudinal and transversal \\ reinforcement, respectively, in RC columns. A total of 12 circular concrete specimens with 205-mm \\ diameter and 800-mm height were cast and tested under different loading conditions. The effect of \\ replacing steel with GFRP reinforcement and changing the spacing of the GFRP helices on the behavior of \\ the specimens was investigated. The experimental results show that the axial load and bending moment \\ capacity of the GFRP-RC columns are smaller than those of the conventional steel-RC columns. However, \\ the ductility of the GFRP-RC columns was very close to the ductility of the steel-RC columns. It is \\ concluded that ignoring the contribution of the GFRP bars in compression leads to a considerable \\ difference between analytical and experimental results.
}

\section{Keywords}

investigations, circular, concrete, columns, reinforced, experimental, gfrp, different, conditions, loading, bars, helices, under

\section{Publication Details}

Hadi, M. N. S., Karim, H. F. \& Sheikh, M. Neaz. (2016). Experimental investigations on circular concrete columns reinforced with GFRP bars and helices under different loading conditions. Journal of Composites for Construction, 20 (4), 04016009-1-04016009-12. 


\title{
Experimental Investigations on Circular Concrete Columns Reinforced with GFRP Bars and Helices under Different Loading Conditions
}

\author{
Muhammad N. S. Hadi ${ }^{1, *}$, F. ASCE \\ ${ }^{1}$ Associate Professor, School of CME Engineering, University of Wollongong, Australia. \\ Email: $\underline{\text { mhadi@uow.edu.au }}$, Corresponding author \\ Hogr Karim ${ }^{2}$ \\ ${ }^{2}$ Ph.D. Candidate, School of CME Engineering, University of Wollongong, Australia. Email: \\ $\underline{\text { hmjkk643@uowmail.edu.au }}$ \\ M. Neaz Sheikh ${ }^{3}$ \\ ${ }^{3}$ Senior Lecturer, School of CME Engineering, University of Wollongong, Australia. Email: \\ $\underline{\text { msheikh@uow.edu.au }}$
}

Glass Fiber Reinforced Polymer (GFRP) bar has emerged as a preferable alternative to steel bar in Reinforced Concrete (RC) members in harsh, corrosive, coastal environments in order to eliminate corrosion problems. However, only limited experimental studies are available on the performance and behavior of concrete columns reinforced with GFRP bars under different loading conditions. This study investigates the use of GFRP bars and GFRP helices (spirals) as longitudinal and transversal reinforcement, respectively, in RC columns. A total of 12 circular concrete specimens with $205 \mathrm{~mm}$ diameter and $800 \mathrm{~mm}$ height were cast and tested under different loading conditions. The effect of replacing steel with GFRP reinforcement and changing the spacing of the GFRP helices on the behavior of the specimens were investigated. The experimental results show that the axial load and bending moment capacity of the GFRPRC columns are smaller than those of the conventional steel-RC columns. However, the ductility of the GFRP-RC columns was very close to the ductility of the steel-RC columns. It 
is concluded that ignoring the contribution of the GFRP bars in compression leads to a considerable difference between analytical and experimental results.

Keywords: Reinforced concrete, Columns, GFRP bars, Eccentric load, Ductility.

\section{Introduction}

Corrosion of conventional steel reinforcing bars is a major concern in Reinforced Concrete (RC) members in harsh, corrosive, coastal environments. Also, the cost of repair and rehabilitation of deteriorated structures due to corrosion of steel reinforcement can be significant (Sheikh and Légeron 2014). In addition, epoxy coating of steel bars may cause the loss of bond between concrete and the steel bars (Sagüés et al. 1994). Fibre Reinforced Polymer (FRP) bars consisting of glass, carbon or aramid fibres encased in a matrix of epoxy, polyester or phenolic thermosetting resins were developed as economical substitute of conventional steel bars to overcome the corrosion problems. FRP materials possess high tensile strength to weight ratio and are nonmagnetic, noncorrosive and nonconductive (Hollaway 2003).

In order to investigate the contribution and the effect of GFRP bars on the concentrically loaded Reinforced Concrete (RC) columns, a few experimental studies were conducted (Alsayed et al. 1999; De Luca 2009; De Luca et al. 2010; Tobbi et al. 2012; Pantelides et al. 2013; Afifi 2013; Afifi et al. 2014a,b; Mohamed et al. 2014; Tobbi et al. 2014). It was reported that the load carrying capacity of the GFRP-RC columns is about 13 to $16 \%$ smaller than the load carrying capacity of the steel-RC columns. Also, the contribution of the GFRP longitudinal bars is about 3 to $10 \%$ of the total load carrying capacity of the RC columns whereas the contribution of the same amount of steel bars is about 12 to $16 \%$. Circular RC 
columns with GFRP helices and columns with the same amount (volumetric ratio) of steel helices can achieve about the same ductility and confined concrete core strength. In addition, few studies were carried out about concrete cylinders reinforced with FRP grids which consist of integrated vertical and horizontal FRP (Saafi 2000; Li 2007; Li and Maricherla 2007; Li and Velamarthy 2008; Ji et al. 2009). It was concluded that the vertical grids mainly increase the axial strength and the horizontal grids results in higher ductility. Also, the confinement effectiveness of concrete cylinders confined with FRP grids is higher than the same amount of FRP laminate. The interfacial shear strength of FRP grids is higher than the regular FRP tube which is beneficial in the pile construction.

A limited number of studies are available on the behavior of FRP-RC columns under eccentric loads. Amer et al. (1996) tested eight rectangular columns reinforced with CFRP bars and steel ties under different eccentric loads (eccentricity=305, 127, 64 and $28 \mathrm{~mm}$ ). They observed that the calculated failure loads were higher than the measured failure loads. However, the calculated and measured failure bending moments were in close agreement. Also, the curvature and deflection of the CFRP-RC columns followed the same pattern of the conventional steel-RC columns. Mirmiran (1998) and Mirmiran et al. (2001) reported that columns reinforced with FRP bars are more susceptible to length effect than their steel-RC columns counterparts because of the lower modulus of elasticity of FRP bars. Also, it was suggested to reduce the slenderness limits by $5 \%$ for AFRP, $15 \%$ for CFRP and $22 \%$ for GFRP bars, if the minimum reinforcement is held at 1\%. Choo et al. (2006a) and Deiveegan and Kumaran (2011) reported that the cross-section strength interaction diagram of FRP-RC columns do not have a balance point because of the linear elastic behavior of FRP bars. Also, in some cases, a brittle tension failure will occur before the strength interaction reaches the pure bending condition because of the rupture of FRP bars in the tension face. Therefore, a set 
of equations were presented in Choo et al. (2006b) to calculate minimum FRP reinforcement ratio for rectangular columns under pure bending to prevent the tensile failure of FRP bars in the tension side. Zadeh and Nanni (2013) carried out numerical analyses on short and slender RC columns reinforced with GFRP bars under different loading conditions. They suggested limiting the ultimate strain of the GFRP bars in tension to $1 \%$ to avoid the exaggerated deflection. Also, the contribution of the GFRP bars in compression was replaced with an equivalent area of concrete.

For the design of GFRP-RC columns, steel bars cannot be simply replaced with GFRP bars because of the differences in the mechanical properties of the steel and GFRP materials (ISIS 2007). Also, because of the lack of experimental studies on GFRP-RC columns and especially for columns under eccentric loading, available design standards do not address the design of GFRP-RC columns. Therefore, experimental investigations are needed to understand and to establish design guidelines for GFRP-RC columns under different loading conditions. This current study is a step towards this goal.

\section{Research Objective}

The majority of RC columns in building structures and bridge piers are under a combination of axial and lateral loads or bending moments. It has been observed from the literature review that the experimental behavior of eccentrically loaded GFRP-RC circular columns has not been adequately investigated. In addition, The American Concrete Institute (ACI) 440.1R-15 (ACI 2015) do not recommend the use of FRP bars in RC columns, while the Japan Society of

Civil Engineers (Sonobe et al. 1997) and Canadian Standard Association (CSA) S806-12 (CSA 2012) permit the use of FRP bars in RC columns with ignoring their contribution in the axial load carrying capacity of the RC columns. Therefore, this study focuses on the behavior 
of GFRP-RC circular columns and compares the behavior of GFRP-RC columns with the behavior of conventional steel-RC columns. For this purpose, a total of 12 circular RC specimens were tested under different loading conditions. The specimens were reinforced with the same amount of steel or GFRP longitudinal bars and with different amounts of transversal GFRP helices.

\section{Experimental Program}

\section{Specimen Design and Preparation}

In this study, 12 small scale circular concrete specimens were cast and tested under different loading conditions. Nine specimens were tested as columns and three specimens were tested as beams. All specimens were $205 \mathrm{~mm}$ in diameter and $800 \mathrm{~mm}$ in height or length (height to diameter $(l / h)$ ratio is equal to 4$)$. The dimensions were chosen to be suitable to the condition and capacity of the available testing equipment in the laboratory. It is noted that vertical support with $l / h$ ratio of greater than or equal to 2.5 is considered as a column in Canadian Standards Association (CSA) S6-06 (CSA 2006). The slenderness ratio of the specimens was about 16, which is within the limit of a short concrete column. In addition, the height of the columns was enough to have a sufficient development length for the longitudinal bars (ACI 2014). The size effect of the RC columns on strength and ductility can be reasonably neglected for a short RC specimens (Marques et al. 2004; Němeček and Bittnar 2004; Silva and Rodriguez 2006; Thériault et al. 2004). The dimensions and reinforcement scheme and configuration of the tested specimens are presented in Fig. 1. The specimens were divided into three groups. Specimens of the first group (S6-S60) (reference specimens) were reinforced longitudinally with six N12 (12 mm diameter deformed bars with $500 \mathrm{MPa}$ nominal tensile strength) steel bars (longitudinal reinforcement ratio=2.06\%) and transversally with R10 (10 mm diameter plain bars with $250 \mathrm{MPa}$ nominal tensile strength) 
steel helices with a pitch of $60 \mathrm{~mm}$ (transversal reinforcement ratio=3.27\%). Specimens of the second group (G6-G60) were reinforced longitudinally with six \#4 (nominal diameter=12.7 mm) GFRP bars (longitudinal reinforcement ratio=2.3\%) and transversally with \#3 (nominal diameter=9.5 mm) GFRP helices with a pitch of $60 \mathrm{~mm}$ (transversal reinforcement ratio $=2.97 \%)$. Specimens of the third group (G6-G30) were reinforced longitudinally with six \#4 GFRP bars and transversally with \#3 GFRP helices with a pitch of $30 \mathrm{~mm}$ (transversal reinforcement ratio $=5.94 \%$ ). The reinforcements (longitudinal and transversal) of the reference group were provided to satisfy the requirements of ACI 318-14 (ACI 2014).

Table 1 provides reinforcement details of the specimens. Each group consists of three columns and one beam. One column was tested concentrically, one was tested under $25 \mathrm{~mm}$ eccentric load, and the one was tested under $50 \mathrm{~mm}$ eccentric load. The beam was tested under four point loading. The specimens are identified by the longitudinal reinforcement material and its number, the transversal reinforcement material and its spacing, and the applied loading condition. For example, Specimen G6-G60-E25 is reinforced longitudinally with six GFRP bars and transversally with a pitch of $60 \mathrm{~mm}$ of GFRP helix and tested under $25 \mathrm{~mm}$ eccentric load. All the testings were conducted at the laboratories of the School of Civil, Mining and Environmental Engineering, University of Wollongong, Australia.

\section{Materials}

All the specimens were cast on the same day using ready mix concrete with an average 28day compressive strength of $37 \mathrm{MPa}$ with a coefficient of variation of $4 \%$. The maximum size of the coarse aggregate of the concrete was $10 \mathrm{~mm}$. Two different diameter steel bars were used to reinforce the steel-RC specimens. Deformed steel N12 and plain mild steel R10 bars were used as longitudinal and transversal reinforcement, respectively. The steel bars were 
tested according to AS 1391-2007 (AS 2007). Figure 2 shows the stress-strain behavior of the tested steel bars. Table 2 reports the experimental tensile strength and modulus of elasticity of the steel bars.

The GFRP bars and helices used in this study had a sand-coated surface to enhance the bond strength between the bars and the surrounding concrete. The GFRP bars and helices were provided by V-Rod Australia (V-Rod 2012). Sand coated \#4 GFRP bars were used for longitudinal reinforcement and sand coated \#3 GFRP helices were used for transverse reinforcement. Cross-sectional areas of the \#3 and \#4 GFRP bars were determined by immersion test according to ISO 104061-1:2015 (ISO 2015). Five pieces of bars of $100 \mathrm{~mm}$ long for each diameter bars were used to calculate representative cross-sectional dimensions. Also, five pieces from the same bar for each of the two diameter bars with a test length of 40 times the diameter of the bars plus the required gripping length at both ends were tested to determine the ultimate tensile strength and strain and the elastic modulus of the GFRP bars as recommended in ASTM D7205-11 (ASTM 2011). The ultimate tensile strength and elastic modulus of the GFRP bars were determined using areas of the bars obtained from immersion test. Figure 3 shows the stress-strain behavior of the tested GFRP bars. Also, the test results are reported in Table 2.

\section{Specimen Fabrication and Instrumentation}

The formwork used for casting the concrete specimens was PVC pipe. The longitudinal steel and GFRP reinforcement were prepared and cut to $760 \mathrm{~mm}$ length in order to have $20 \mathrm{~mm}$ clear cover at the top and bottom of the reinforcement cage. The transverse steel helix was prepared by forming a coil with $170 \mathrm{~mm}$ outer diameter and $60 \mathrm{~mm}$ pitch. The GFRP helices were manufactured in a coil shape with $170 \mathrm{~mm}$ outer diameter by the manufacturer (V-Rod 
2012). The clear covers to the face of the helices were $17.5 \mathrm{~mm}$ for all the specimens. The steel and GFRP reinforcement cages assembled for the specimens are shown in Fig. 4. The PVC moulds were fixed vertically in a wooden formwork and the cages were inserted into the PVC moulds. Concrete was placed into the formwork in three stages. In every stage concrete was vibrated using an electric vibrator to compact and to remove any air bubbles. The specimens were cured by covering them with wet hessian and plastic sheets to maintain the moisture conditions. The curing process lasted 28 days before testing the specimens.

The specimens were instrumented internally and externally to capture the axial and lateral deformations of the specimens and the axial and hoop strain in the reinforcement. For concentric loading, the axial deformation of the columns was recorded by two Linear Variable Differential Transducers (LVDT) attached vertically to the loading plate at two opposite corners. Also, before casting the concrete, two electrical strain gages were attached at the mid-height in the two opposite longitudinal bars (one in the compression side and the other in the tension side) in order to capture the axial strain at these bars. In addition, two electrical strain gages were attached at mid-height in the two opposite sides of the helical reinforcement to measure the strain in the hoop direction. In addition, a lazer triangulation was used for the columns under eccentric loads to record the lateral deformation at the mid-height of the columns. For the flexural loading, the lazer triangulation was fixed vertically at the bottom of the beams to record the mid-span deflection.

\section{Testing Procedure}

The Denison $5000 \mathrm{kN}$ compression testing machine was used to test the specimens. The top and bottom of the column specimens were wrapped by a single layer of CFRP sheet to prevent the premature failure of the concrete during axial compression tests. The width of the 
CFRP sheet was $75 \mathrm{~mm}$. Also, both ends of the columns were capped with high-strength plaster in order to distribute the load uniformly. The eccentric loading system consisted of two steel loading heads with two steel plates on top and bottom of the columns with an overhang edge (or loading knives) as shown in Fig. 5(a). Also, the flexural loading system consisted of two rigs at top and bottom of the beams. The span of the beam specimens was $700 \mathrm{~mm}$ and spacing between the loads was $233.3 \mathrm{~mm}$, as shown in Fig. 5(b).

The test stared with a force-controlled pre-loading the specimens at a rate of $2 \mathrm{kN} / \mathrm{s}$ to about $10 \%$ of the yield loads of the specimens and then unloading the specimens to $20 \mathrm{kN}$. Afterwards, the test resumed with displacement control loading $(0.005 \mathrm{~mm} / \mathrm{s})$ until the resistance of the specimens dropped to $30 \%$ of the yield load or until the axial displacement reached $40 \mathrm{~mm}$. The applied axial load and displacement of the tested specimens were recorded through the internal load cell of the Denison testing machine. Also, the experimental test results were recorded through the LVDTs, lazer triangulation, the strain gages, and a sensor located on the bottom of the testing machine to capture the applied axial load and displacement of the specimens. The LVDTs, strain gages, the lazer triangulation and the sensor were connected to a data-logger to record the readings at every 2 seconds. Typical test set ups for a column and a beam specimens are shown in Fig. 6.

\section{Experimental Results and Analysis}

\section{Failure Modes}

All the specimens were tested to failure. The failure modes depended on the reinforcement materials and the loading conditions. The failure of the reference specimen (S6-S60-C) under concentric loading was caused by buckling of the longitudinal bars followed by crushing of the concrete core. However, the failure of the GFRP-RC specimens under concentric loads 
was due to the rupture of the GFRP helices followed by buckling and crushing of the longitudinal bars and the concrete core. The specimens under eccentric loads failed due to crushing of the concrete in the compression side. The spacing of the horizontal cracks in the tension side depended on the reinforcing materials and the pitch of the helices. The spacing of

the cracks in the steel-RC specimens was about $60 \mathrm{~mm}$, which was approximately $6.3 \%$ smaller than the crack spacing of the corresponding GFRP-RC specimens. The spacing of the cracks in the specimens with $30 \mathrm{~mm}$ pitch of GFRP helix (about $54 \mathrm{~mm}$ ) were about $15.6 \%$ smaller than the specimens with $60 \mathrm{~mm}$ pitch of GFRP helix (about $64 \mathrm{~mm}$ ). The failure of the beam specimens (S6-S60-F and G6-G30-F) was also caused by concrete crushing in the compression region. The failure of Specimen G6-G30-F was marked as a brittle failure because of the behavior of GFRP bars which is linear elastic till failure. However, Specimen G6-G60-F failed in shear after reaching the yield load because the provided lateral reinforcement was not enough to carry the shear force till the ultimate flexural load carrying capacity. Also, the shear span of the tested beam specimens was less than twice of the effective depth of the cross-section. The failure modes of the tested specimens are shown in Fig. 7.

\section{Behavior of Column Specimens}

In general, the axial load and deformation (axial or lateral) behavior of the column specimens can be divided into three phases. The first phase is the ascending part of the load-deformation curve. The second phase is a sharp descend of the axial load within a small amount of axial and lateral deformation which is caused by the spalling of concrete cover. The third phase is a descending or an ascending axial load of the columns with increasing axial and lateral deformation till failure of the column specimens. There were also two main points which were the first and the second peak load in the load-deformation curve of the GFRP-RC 
specimens. The first peak load in the load-deformation curve shows the maximum axial load carried by the reinforced gross concrete cross-section (concrete cover and core). At this point, the concrete covers may have been cracked and cover spalling started afterwards. The second peak load expresses the maximum axial load carried by the confined concrete core (without concrete cover). In some cases, the second peak load was greater than the first peak load depending on the confinement conditions. However, there was only a peak load in the loaddeformation curve of the steel-RC specimens and the reason will be clarified in the following paragraph. Table 3 and 4 report the experimental results in terms of first and second peak loads and ductility of the column specimens. The ductility based on energy absorption of the column specimens after the first peak load was used in this study. The ductility $\left(I_{5}\right.$ and $\left.I_{10}\right)$ defined in Foster and Attard (1997) was computed based on area under the axial load-axial deformation curves. $I_{5}$ is the area of $A D E$ (Fig. 8) divided by the area $A B C$, where $C$ corresponds to the Point $\Delta_{75}$ and $E$ corresponds to the Point $3 \Delta_{75}$. Also, $I_{10}$ is the area of $A F G$ divided by the area of $A B C$, where $G$ corresponds to the Point $5.5 \Delta_{75}$. Point $\Delta_{75}$ is the deformation corresponding to the intersection point of an extension line through the origin and 0.75 times of the first peak axial load and a horizontal line from the first peak axial load, as shown in the Fig. 8 .

Figure 9 shows the axial load-axial deformation behavior for the tested columns under concentric loads. It can be seen that the ascending part of the load-deformation curve of the columns followed the same pattern till first peak load and was dominated mainly by the concrete strength. It can be noticed that the ascending part of Specimen G6-G60-C is slightly smaller than the other specimens, although the difference is not significant. This slight difference may be because concrete is a composite and non-homogeneous material that different factors such as placing, compacting and curing may affect the strength and 
properties of concrete (Neville 2005). Specimen G6-G60-C obtained about 20\% lower first peak load than the first peak load of the reference specimen (S6-S60-C) because of the lower modulus of elasticity of the GFRP bars. However, the ductility of the GFRP-RC specimen (G6-G60-C) was slightly greater than the reference specimen (S6-S60-C). This is because the axial and hoop strain of the GFRP bars and helices at first peak load were less than $20 \%$ and $5 \%$, respectively, of their ultimate strain. Whereas, the steel bars reached to yield strain and the steel helices reached to about $50 \%$ of yield strain at first peak load. Therefore, it is expected that the GFRP-RC columns will carry more loads and deformations after first peak load. Therefore, most of the GFRP-RC column specimens achieved greater second peak load than the firs peak load. Also, it can be observed that the contribution of the longitudinal steel bars in the first peak load of the columns was about $26.6 \%$. The contribution of the steel bars was about two times greater than the contribution of the longitudinal GFRP bars (about 13.4\%). Reducing the spacing of the GFRP helices from 60 to $30 \mathrm{~mm}$ led to increase in the first peak load and ductility by about $7 \%$ and $29 \%$, respectively. It can also be observed that increasing the lateral GFRP reinforcement could improve the ductility more than the first peak load. This is because the GFRP helices were not completely activated before the cover spalling. The strains in the GFRP helices were smaller than 5\% of the ultimate tensile strain. In contrast, after cover spalling and dilation of the concrete core, the GFRP helices were activated and resulted in improving the second peak load and ductility of the GFRP-RC column specimens.

Figure 10 shows the axial load versus the axial and lateral deformation behavior of the tested column specimens under $25 \mathrm{~mm}$ eccentric loads. In general, the GFRP-RC columns under eccentric loads exhibited a slightly smaller stiffness in the ascending part of the loaddeformation curves than the steel-RC columns because of the lower modulus of elasticity of 
the GFRP bars than the steel bars. Similar to the columns under concentric loads, the GFRPRC column gained lower first peak load by about $13 \%$ than the first peak load of reference column. Also, the ductility of Specimen G6-G60-E25 was slightly greater than the ductility of the reference specimen (S6-S60-E25). Increasing the amount of GFRP helices did not increase the first peak load of the column specimens because the smaller spacing of GFRP helix created a separation plane between the concrete cover shell and the concrete core which led to instability of the concrete shell and cover spalling at an early stage (Razvi and Saatcioglu 1994; Pessiki and Pieroni 1997). However, the ductility and second peak load of the columns increased due to the reduction of the spacing of the GFRP helices from $60 \mathrm{~mm}$ to $30 \mathrm{~mm}$.

Figure 11 shows the axial load versus axial and lateral deformation behavior of the tested column specimens under $50 \mathrm{~mm}$ eccentric loads. Specimen G6-G60-E50 achieved about 17\% lower first peak load and slightly greater ductility compared to the first peak load and ductility of the reference specimen (S6-S60-E50). Similar to the specimens under $25 \mathrm{~mm}$ eccentric loads, the specimens with $60 \mathrm{~mm}$ pitch achieved about $3 \%$ greater first peak load than the first peak load of specimens with $30 \mathrm{~mm}$ pitch. However, the ductility $\left(I_{10}\right)$ increased by about $57 \%$ as a result of the reduction of helices spacing from $60 \mathrm{~mm}$ to $30 \mathrm{~mm}$. This is because the smaller spacing helix led to better confined concrete core and allowed the columns to sustain more loads with increasing axial deformation.

The effects of eccentricity on the behavior of the column specimens have been shown in Fig. 12. In general, increase in the eccentricity led to decrease the performance of the column specimens in terms of axial load carrying capacity and ductility. In general, the first peak load 
of the column specimens decreased by about 40 and $60 \%$ under the 25 and $50 \mathrm{~mm}$ eccentricity, respectively, compared to the column specimens under concentric load.

\section{Behavior of Beam Specimens}

Figure 13 shows the load versus mid-span deflection behavior of the tested beam specimens under flexural loadings. It can be observed that the ascending part of the load-deflection curve of the steel-RC beam has greater stiffness than the GFRP-RC beams because of the smaller modulus of elasticity of the GFRP bars. The load and mid-span deflection curve of the steel$\mathrm{RC}$ beam consisted of three parts which represent the yielding of the reinforcement in each layer. The first (Point A to B) and second (Point B to C) ascending parts of the load and midspan deflection curve represent the yielding of the first and the second layer of the steel reinforcement, respectively, followed by stabilizing the load-deflection curve (Point C to D). With the progression of the applied load, the concrete in the compression zone reached its crushing strain and led to complete failure of the steel-RC beam specimen. However, the load-deflection behavior of the GFRP-RC beams consisted of only an ascending part and followed by a descending part because of the linear elastic stress-strain behavior of GFRP bars. However, the descending part of the load-deflection curve of Specimen G6-G60-F is less steep than Specimen G6-G30-F because Specimen G6-G60-F failed in shear. Table 5 reports the experimental results of the tested beams.

\section{Peak Axial Load-Bending Moment Diagrams}

As mentioned above, there were two main points which are the first and the second peak loads in the load-deformation curve of the GFRP-RC specimens. Therefore, two sets of the peak axial load-bending moment diagrams were drawn for the GFRP-RC specimen based on the first and the second peak loads. In this study, four points which are concentric, 25 and 50 
mm eccentric and flexural loading were considered in drawing the experimental peak axial load-bending moment diagrams. The experimental bending moments at the mid-height of the columns under eccentric loads were calculated as,

$$
\begin{aligned}
& M_{1}=P_{\text {peak }, 1}\left(e+\delta_{1}\right) \\
& M_{2}=P_{\text {peak }, 2}\left(e+\delta_{2}\right)
\end{aligned}
$$

where $M_{1}$ and $\delta_{1}$ are the moment and lateral deformation corresponding to the first peak load $\left(P_{\text {peak,1 }}\right)$, respectively, $M_{2}$ and $\delta_{2}$ are the moment and lateral deformation corresponding to the second peak load $\left(P_{\text {peak,2 }}\right)$, respectively, and $e$ is the applied initial eccentricity. The experimental bending moments at mid-span of the beams were calculated as,

$$
\begin{aligned}
& M_{1}=\frac{1}{2} P_{\text {peak }, 1} a \\
& M_{2}=\frac{1}{2} P_{\text {peak }, 2} a
\end{aligned}
$$

where, $a$ is the shear span length, or the distance between the support and the closer loading point ( $a=233.3 \mathrm{~mm}$ in this study). The experimental moment of the column and beam specimens are reported in Tables 4 and 5, respectively. The experimental confined concrete strength $\left(f_{c c}\right)$ of the column specimens under concentric loads was calculated as,

$$
f_{c c}=\frac{P_{p e a k, 2}-P_{b a r, 2}}{A_{c c}}
$$

where $P_{\text {peak,2 }}$ and $P_{b a r, 2}$ are the second peak load and the corresponding loads carried by the longitudinal bars, respectively, and $A_{c c}$ is the area of confined concrete core with diameter $d_{c}$ that through the centre of the GFRP helices. The experimental results of the confined concrete strength are reported in Table 3.

Figure 14(a) shows the peak axial load-bending moment diagram for the tested specimens in terms of the first peak loads. It can be seen that the conventional steel-RC specimens obtained greater load and moment capacity than the GFRP-RC specimens because of greater modulus 
of elasticity of the steel reinforcement. Reduction in the spacing of the GFRP helices did not considerably change the peak axial load-bending moment diagram of the GFRP-RC specimens because the passive confinement due to the GFRP helices is not considerably activated in the first peak load. However, it is clear in Fig. 14(b) that the GFRP bars and helices improved the peak axial load-bending moment diagrams of the GFRP-RC specimens. This is because the modulus of elasticity of the GFRP bars is much smaller than the steel bars. Therefore, larger deformation and lateral expansion are needed to achieve higher stress in the GFRP bars and helices.

Figure 15 shows a typical axial load-axial deformation curve of the GFRP-RC specimens. Similar to the experimental peak axial load-bending moment diagrams, two analytical peak axial load-bending moment diagrams were drawn for the GFRP-RC specimens corresponding to the first and the second peak loads. The analytical peak axial load-bending moment diagrams were drawn based on five points (Points A to E) as demonstrated in Fig. 16. These points (Points A to E) can demonstrate the entire peak axial load-bending moment diagram for FRP-RC cross-sections reasonably accurately results for over reinforced FRP-RC crosssections. It is noted that the analytical peak axial load-bending moment diagrams presented herein did not consider the slenderness effect, as the specimens were considered short specimens.

The GFRP bars do not reach the ultimate strain when the concrete reach the ultimate strain. Also, the ultimate compressive strength of the GFRP bars is smaller than their ultimate tensile strength. Therefore, the nominal load carrying capacity of GFRP-RC columns under concentric loads (Point A if Fig. 16) can be calculated based on the CSA S806-12 (CSA 2012), which ignores the contribution of the longitudinal GFRP bars. 


$$
\begin{gathered}
P_{n 1}=0.85 f_{c}^{\prime} A_{g} \\
P_{n 2}=0.85 f_{c c} A_{c c}
\end{gathered}
$$

where $P_{n 1}$ and $P_{n 2}$ are the nominal load carrying capacity of the columns corresponding to the first and the second peak loads, respectively, $A_{g}$ is the gross area of the concrete crosssection with diameter $h$ and $f_{c}^{\prime}$ and $f_{c c}$ are the unconfined concrete cylinder compressive strength at 28 days and the confined concrete core strength, respectively. The $f_{c c}$ of the specimens confined with GFRP helices cannot analytically be calculated because the available equations is introduced for steel helix, tubes and FRP wrapping. Therefore, the experimental $f_{c c}$ of the specimens under concentric loads were used in the analytical calculations.

Also it is reasonable to assume that the strain in the GFRP bars is approximately equal to the concrete ultimate strain, which is equal to 0.003 for the first peak load as defined in ACI 31814 (ACI 2014) and equal to $\varepsilon_{c c}$ for the second peak load. As a result, the nominal load carrying capacity of the GFRP-RC columns under concentric loads can also be computed by Eq. (8) and (9) for the first and the second peak loads, respectively. Based on the experimental study of Deitz et al. (2003), it can be assumed that the compressive and tensile moduli of elasticity of GFRP bars is approximately equal.

$$
\begin{gathered}
P_{n 1}=0.85 f_{c}^{\prime}\left(A_{g}-A_{f}\right)+0.003 E_{f} A_{f} \\
P_{n 2}=0.85 f_{c c}\left(A_{c}-A_{f}\right)+\varepsilon_{c c} E_{f} A_{f}
\end{gathered}
$$

where $A_{f}$ is the area of the longitudinal GFRP bars that determined from immersion test, and $E_{f}$ is the modulus of elasticity of the longitudinal GFRP bars.

The analytical peak axial load-bending moment diagrams for the GFRP-RC specimens under eccentric and flexural loads (Points B to E) were calculated based on the principles of equilibrium and strain compatibility in the concrete cross-sections between GFRP bars and 
concrete. The equivalent rectangular stress block as defined in ACI 318-14 (ACI 2014) and Mohamed and Masmoudi (2010) were used to calculate the concrete stress in the compression region for the first and the second peak loads, respectively. A linear elastic stress-strain relationship was used for the GFRP bars in tension and compression. In order to investigate the effect and contribution of the GFRP bars in compression, two different calculation procedures were conducted for the GFRP-RC columns. In the first calculation procedure, the contribution of the GFRP bars in the compression region was ignored and replaced with an equivalent area of concrete, as recommended by Zadeh and Nanni (2013). However, in the second calculation procedure, the contribution of the GFRP bars was considered.

In order to calculate the peak axial load-bending moment diagram in the Points B to E, arbitrarily values for $Z$ were taken as shown in Fig. 16, where $Z$ is the ratio of maximum tensile strain of the GFRP bars in the tension side to the ultimate compressive strain in the extreme compression fiber in the compression side. In this study, compression strain, stress and force are considered as positive and tensile strain, stress and force are considered as negative. From Fig. 17(a) and (b), by similar triangles, the depth of neutral axis $(c)$ and strain in each of the GFRP bars $\left(\varepsilon_{f i}\right)$ can be calculated as,

$$
\begin{gathered}
c=\frac{d_{1}}{1-Z} \\
\varepsilon_{f i}=\left(1-\frac{d_{i}}{c}\right) \varepsilon_{c u}
\end{gathered}
$$

where $d_{i}$ is the distance between the centre of the $i^{\text {th }}$ GFRP bar to the extreme compression fiber in the compression side, $\varepsilon_{c u}$ is the ultimate concrete compressive strain which is equal to 0.003 in the first peak load and equal to $\varepsilon_{c c}$ in the second peak load. Also, the forces in each of the GFRP bars $\left(F_{f i}\right)$ and the compression force in concrete in the compression side $\left(F_{c}\right)$ can be determined as, 


$$
\begin{gathered}
F_{f i}=\varepsilon_{f i} E_{f} A_{f i} \\
F_{c}=\alpha f_{c u} A_{c} \\
A_{c}=(\theta-\sin \theta \cos \theta) r^{2} \\
\theta=\cos ^{-1}\left(1-\frac{\beta c}{r}\right)
\end{gathered}
$$

where $A_{f i}$ and $A_{c}$ are the areas of the $i^{\text {th }}$ GFRP bar and concrete in the compression side, respectively, $f_{c u}$ is the maximum concrete compressive strength which is equal to $f_{c}^{\prime}$ in the first peak load and equal to $f_{c c}$ in the second peak load. Also, $\alpha$ is the ratio of the member concrete compressive strength to the cylinder concrete compressive strength at age 28 days, $\beta$ is the ratio of height of the equivalent rectangular stress block to the depth of neutral axis as defined in ACI 318-14 (ACI 2014). The $r$ is the radius of the concrete cross-section which is equal to $h / 2$ in the first peak load and equal to $d_{c} / 2$ in the second peak load (Fig. 15 and 17).

The nominal axial load $\left(P_{n}\right)$ and bending moment $\left(M_{n}\right)$ of the GFRP-RC specimens can be calculated by summation of the forces in the concrete cross-section and taking moment of the forces around the centroid of the concrete cross-section:

$$
\begin{gathered}
P_{n}=F_{c}+\sum F_{f i} \\
M_{n}=F_{c} \bar{y}+\sum F_{f i}\left(r-d_{i}\right) \\
\bar{y}=\frac{2 r}{3}\left(\frac{\sin ^{3} \theta}{\theta-\sin \theta \cos \theta}\right)
\end{gathered}
$$

where $\bar{y}$ is the distance between the centroid of concrete in the compression side to the centroid of the concrete cross-section.

Figure 18(a) and (b) show the peak axial load-bending moment diagrams of the experimental and calculated results corresponding to the first and the second peak loads, respectively, for 
the GFRP-RC specimens. Two analytical peak axial load-bending moment diagrams were drawn for the GFRP-RC specimens. In the first curve, the contribution of the GFRP bars in compression was ignored. In the second curve, the contributions of the GFRP bars in compression were taken into account. It can be seen that there is a large difference between the experimental and calculated results when the effect of the GFRP bars was ignored in the compression region. However, the experimental results are in a better agreement with the calculated results when the effect of the GFRP bars in compression is taken into account. The experimental bending moments of the GFRP-RC beam specimens were greater than the calculated results. This may be because the shear span of the RC beam specimens was smaller than twice of the effect depth of the concrete cross-section. Eventually, it can be concluded that ignoring the contribution of GFRP bars in compression is not reasonable and very conservative.

\section{Conclusions}

In this study, a total of 12 circular RC specimens were tested under different loading conditions. The specimens were reinforced with conventional steel bars and helices and GFRP bars and different pitches of GFRP helices. The effect of replacing steel reinforcement with the same amount of GFRP reinforcement and the effect of spacing of the GFRP helices on the behavior of the RC specimens were investigated. Based on the experimental investigations carried out in this study, the following conclusions can be drawn:

1. Replacing the steel bars and helices with the same amount of GFRP bars and helices led to reductions in the axial load carrying capacity and bending moment of the specimens under different loading conditions. Also, increase in the applied initial eccentricity caused a reduction in the performance of the column specimens in terms of axial load carrying capacity and ductility. 
2. The contribution of the longitudinal steel bars in the load carrying capacity of the column specimens under concentric load was about two times of the contribution of the longitudinal GFRP bars. Whereas, the ductility of the GFRP-RC column specimens was slightly greater than the ductility of the reference steel-RC column specimens under different loading conditions.

3. Reduction of the GFRP helices pitch from 60 to $30 \mathrm{~mm}$ led to improvement in the performance of the GFRP-RC specimens in terms of load carrying capacity, bending moment, and ductility.

4. The load carrying capacity and bending moment of the GFRP-RC specimens can be calculated by the same principles used for the conventional steel-RC specimens. Also, ignoring the contribution of the GFRP bars in compression may result in a large discrepancy between the experimental and analytical results.

\section{Acknowledgments}

The authors would like to thank University of Wollongong and technical officers at the High Bay laboratory, especially Mr. Fernando Escribano and Mr. Ritchie Mclean for their help in the experimental program of this study. Also, the second author would like to thank Kurdistan Regional Government of Iraq and University of Wollongong for the support of his Ph.D. scholarship.

\section{References}

ACI (American Concrete Institute). (2014). "Building code requirements for structural concrete." ACI 318-14M, Farmington Hills, MI.

ACI (American Concrete Institute). (2015). "Guide for the design and construction of concrete reinforced with FRP bars." ACI 440.1R-15, Farmington Hills, MI. 
Afifi M. Z. (2013). "Behavior of circular concrete columns reinforced with FRP bars and stirrups", Ph.D dissertation, University of Sherbrooke, Sherbrooke, Canada.

Afifi M. Z., Mohamed H. M. and Benmokrane B. (2014a). "Axial capacity of circular concrete columns reinforced with GFRP bars and spirals." J. Compos. Constr., 10.1061/(ASCE)CC.1943-5614.0000438, 04013017.

Afifi M. Z., Mohamed H. M. and Benmokrane B. (2014b). "Strength and axial behavior of circular concrete columns reinforced with CFRP bars and spirals." J. Compos. Constr., 10.1061/(ASCE)CC.1943-5614.0000430, 04013035.

Alsayed S., Al-Salloum Y., Almusallam T. and Amjad M. (1999). "Concrete columns reinforced by glass fiber reinforced polymer rods." Proc., 4th Int. Symp. on FiberReinforced Polymer Reinforcement for Reinforced Concrete Structures, SP-188, C. W. Dolan, S. H. Rizkalla, and A. Nanni, American Concrete Institute, Farmington Hills, MI, 103-112.

Amer A., Arockiasamy M. and Shahawy M. (1996). "Ultimate strength of eccentrically loaded concrete columns reinforced with CFRP bars" Proc., 2nd Int. Conf. on Advanced Composite Materials in Bridges and Strucures, ACMBS-II, e. M. M. El-Badry, ed., Montereal, Quebec, 209-216.

AS (Australian Standard). (2007). "Metallic materials - Tensile testing at ambient temperature." AS 1391-2007, Sydney, NSW.

ASTM (American Society for Testing and Materials). (2011). "Standard test method for tensile properties of fiber reinforced polymer matrix composite bars." ASTM D7205/D7205M-11, West Conshohocken, PA.

Choo C. C., Harik I. E. and Gesund H. (2006a). "Strength of rectangular concrete columns reinforced with fiber-reinforced polymer bars." ACI Struct. J., 103 (3), 452-459. 
Choo C. C., Harik I. E. and Gesund H. (2006b). "Minimum reinforcement ratio for fiberreinforced polymer reinforced concrete rectangular columns." ACI Struct. J., 103 (3), $460-466$.

CSA (Canadian Standards Association). (2006). "Canadian highway bridge design code." CAN/CSA S6-06, Rexdale, ON, Canada.

CSA (Canadian Standards Association). (2012). "Design and construction of building structures with fibre reinforced polymers." CAN/CSA S806-12, Rexdale, ON, Canada.

De Luca A. (2009). "Behavior of full-scale reinforced concrete members with external confinement or internal composite reinforcement under pure axial load" Ph.D. Dissertation, University of Miami, Coral Gables, Florida.

De Luca A., Matta F. and Nanni A. (2010). "Behavior of full-scale glass fiber-reinforced polymer reinforced concrete columns under axial load." ACI Struct. J., 107 (5), 589-596.

Deitz D., Harik I. and Gesund H. (2003). "Physical properties of glass fiber reinforced polymer rebars in compression." J. Compos. Constr., 10.1061/(ASCE)10900268(2003)7:4(363), 7:363-366.

Deiveegan A. and Kumaran G. (2011). "Experimental and reliability studies on the behaviour of concrete columns reinforced internally with glass fibre reinforced polymer reinforcements." J. Struct. Eng. (Madras), 38 (5), 457-475.

Foster S. J. and Attard M. M. (1997). "Experimental tests on eccentrically loaded highstrength concrete columns." ACI Struct. J., 94 (3), 295-303.

Hollaway L. C. (2003). "The evolution of and the way forward for advanced polymer composites in the civil infrastructure." Constr. Build. Mater., 17 (6-7), 365-378.

ISIS Canada. (2007). "Reinforcing Concrete Structures with Fibre Reinforced Polymers." The Canadian Network of Centres of Excellence on Intelligent Sensing for Innovative Structures, http://www.isiscanada.com. 
ISO (International Standard). (2015). "Fibre-reinforced polymer (FRP) reinforcement of concrete - Test methods - Part 1: FRP bars and grids." ISO 10406-1:2015, Switzerland.

Ji G., Ouyang Z. and Li G. (2009). "Experimental investigation into the interfacial shear strength of AGS-FRP tube confined concrete pile." Eng. Struct., 31 (10), 2309-2316.

Li G. (2007). "Experimental study of hybrid composite cylinders." Compos. Struct., 78 (2), 170-181.

Li G. and Maricherla D. (2007). "Advanced grid stiffened fiber reinforced plastic tube encased concrete cylinders." J. Compos. Mater., 41 (15), 1803-1824.

Li G. and Velamarthy R. C. (2008). "Fabricating, testing, and modeling of advanced grid stiffened fiber reinforced polymer tube encased concrete cylinders." J. Compos. Mater., $42(11), 1103-1124$.

Marques S. P. C., Codá Dos Santos Cavalcanti Marques D., Lins Da Silva J. and Cavalcante M. A. A. (2004). "Model for analysis of short columns of concrete confined by fiberreinforced polymer." J. Compos. Constr., 10.1061/(ASCE)1090-0268(2004)8:4(332), 8:332-340.

Mirmiran A. (1998). "Length effects on FRP-reinforced concrete columns" 2nd Int. Conf. on Composites in Infrastructure1, Tucson, AZ, 518-532.

Mirmiran A., Yuan W. and Chen X. (2001). "Design for slenderness in concrete columns internally reinforced with fiber-reinforced polymer bars." ACI Struct. J., 98 (1), 116-125.

Mohamed H. M., Afifi M. Z. and Benmokrane B. (2014). "Performance evaluation of concrete columns reinforced longitudinally with FRP bars and confined with FRP hoops and spirals under axial load." J. Bridge Eng., 10.1061/(ASCE)BE.1943-5592.0000590, 04014020.

Mohamed H. M. and Masmoudi R. (2010). "Flexural strength and behavior of steel and FRPreinforced concrete-filled FRP tube beams." Eng. Struct., 32 (11), 3789-3800. 
Němeček J. and Bittnar Z. (2004). "Experimental investigation and numerical simulation of post-peak behavior and size effect of reinforced concrete columns." Mater. Struct., 37 (3), 161-169.

Neville A. M. (2005). Properties of concrete: Fourth and final edition standards updated to 2002, London, U.K.

Pantelides C. P., Gibbons M. E. and Reaveley L. D. (2013). "Axial load behavior of concrete columns confined with GFRP spirals." J. Compos. Constr., 10.1061/(ASCE)CC.1943$5614.0000357,17: 305-313$

Pessiki S. and Pieroni A. (1997). "Axial load behavior of large scale spirally reinforced highstrength concrete columns." ACI Struct. J., 94 (3), 304-313.

Razvi S. R. and Saatcioglu M. (1994). "Strength and deformability of confined high-strength concrete columns." ACI Struct. J., 91 (6), 678-687.

Saafi M. (2000). "Design and fabrication of FRP grids for aerospace and civil engineering applications." J. Aerosp. Eng., 13 (4), 144-149.

Sagüés A. A., Lee J. B., Chang X., Pickering H., Nystrom E., Carpenter W., Kranc S., Simmons T., Boucher B. and Hierholzer S. (1994). "Corrosion of epoxy coated rebar in Florida bridges", Final Report to Florida DOT WPI, University of South Florida, Tampa, Florida.

Sheikh M. N. and Légeron F. (2014). "Performance based seismic assessment of bridges designed according to Canadian Highway Bridge Design Code." Can. J. Civ. Eng., 41 (9), 777-787.

Silva M. A. G. and Rodriguez C. C. (2006). "Size and relative stiffness effects on compressive failure of concrete columns wrapped with glass FRP." J. Mater. Civ. Eng., $18(3), 334-342$. 
Sonobe Y., Fukuyama H., Okamoto T., Kani N., Kimura K., Kobayashi K., Masuda Y., Matsuzaki Y., Mochizuki S., Nagasaka T., Shimizu A., Tanano H., Tanigaki M. and Teshigawara M. (1997). "Design guidelines of FRP reinforced concrete building structures." J. Compos. Constr., 1 (3), 90-114.

Thériault M., Neale K. W. and Claude S. (2004). "Fiber-reinforced polymer-confined circular concrete columns: Investigation of size and slenderness effects." J. Compos. Constr., 10.1061/(ASCE)1090-0268(2004)8:4(323), 8:323-331.

Tobbi H., Farghaly A. S. and Benmokrane B. (2012). "Concrete columns reinforced longitudinally and transversally with glass fiber-reinforced polymer bars." ACI Struct. J., 109 (4), 551-558.

Tobbi H., Farghaly A. S. and Benmokrane B. (2014). "Behavior of concentrically loaded fiber-reinforced polymer reinforced concrete columns with varying reinforcement types and ratios." ACI Struct. J., 111 (2).

V-Rod (2012). "Composite reinforcing rods technical data sheet." Largs Bay SA, Australia.

Zadeh H. J. and Nanni A. (2013). "Design of RC columns using glass FRP reinforcement." J. Compos. Constr., 10.1061/(ASCE)CC.1943-5614.0000354, 17:294-304. 


\section{List of Tables}

Table 1. Test Matrix

Table 2. Mechanical properties of steel and GFRP bars

Table 3. Experimental results of the tested column specimens under concentric loads

Table 4. Experimental results of the tested column specimens under eccentric loads

Table 5. Experimental results of the tested beam specimens 


\section{List of Figures}

Fig. 1. Reinforcement details and dimensions of the specimens

Fig. 2. Stress-strain behavior of steel bars

Fig. 3. Stress-strain behavior of GFRP bars

Fig. 4. Reinforcement cages

Fig. 5. Testing of specimens: (a) columns under eccentric load; and (b) beams under flexural load

Fig. 6. Typical testing set up of the tested specimens: (a) Column specimen; and (b) Beam specimen

Fig. 7. Failure modes of tested specimens

Fig. 8. Ductility measurement for the column specimens

Fig. 9. Axial load-axial deformation behavior of column specimens tested under concentric loads

Fig. 10. Axial load-deformation behavior of column specimens tested under $25 \mathrm{~mm}$ eccentricity

Fig. 11. Axial load-deformation behavior of column specimens tested under $50 \mathrm{~mm}$ eccentricity

Fig. 12. Axial load-axial deformation behavior of column specimens tested under eccentric axial load: (a) S6-S60; (b) G6-G60; and (c) G6-G30

Fig. 13. Load-deflection behavior of beam specimens tested under flexural loads

Fig. 14. Experimental peak axial load-bending moment diagram of the tested specimens: (a) First peak load; and (b) Second peak load

Fig. 15. Typical axial load-axial deformation behavior of GFRP-RC column specimens

Fig. 16. Drawing of analytical peak axial load-bending moment diagrams 
Fig. 17. Stress and strain profile of GFRP-RC cross-section: (a) First peak load; and (b) Second peak load

Fig. 18. Experimental and calculated peak axial load-bending moment diagrams: (a) First peak load; and (b) Second peak load.

Note: Calculation 1: contribution of the GFRP bars was ignored in compression, and Calculation 2: contribution of the GFRP bars was taken into account in compression 
Table 1. Test Matrix

\begin{tabular}{|c|c|c|c|c|}
\hline Group & Specimen & $\begin{array}{l}\text { Longitudinal } \\
\text { reinforcement }\end{array}$ & $\begin{array}{c}\text { Transversal } \\
\text { reinforcement }\end{array}$ & Test eccentricity \\
\hline \multirow{4}{*}{ S6-S60 } & S6-S60-C & \multirow{4}{*}{$\begin{array}{l}\text { Steel } \\
6 \mathrm{~N} 12\end{array}$} & \multirow{4}{*}{$\begin{array}{c}\text { Steel } \\
\text { R10@60 mm pitch }\end{array}$} & Concentric \\
\hline & S6-S60-E25 & & & $25 \mathrm{~mm}$ \\
\hline & S6-S60-E50 & & & $50 \mathrm{~mm}$ \\
\hline & S6-S60-F & & & Flexural \\
\hline \multirow{4}{*}{ G6-G60 } & G6-G60-C & \multirow{4}{*}{$\begin{array}{l}\text { GFRP } \\
6 \# 4\end{array}$} & \multirow{4}{*}{$\begin{array}{c}\text { GFRP } \\
\text { \#3@60 mm pitch }\end{array}$} & Concentric \\
\hline & G6-G60-E25 & & & $25 \mathrm{~mm}$ \\
\hline & G6-G60-E50 & & & $50 \mathrm{~mm}$ \\
\hline & G6-G60-F & & & Flexural \\
\hline \multirow{4}{*}{ G6-G30 } & G6-G30-C & \multirow{4}{*}{$\begin{array}{l}\text { GFRP } \\
6 \# 4\end{array}$} & \multirow{4}{*}{$\begin{array}{c}\text { GFRP } \\
\text { \#3@30 mm pitch }\end{array}$} & Concentric \\
\hline & G6-G30-E25 & & & $25 \mathrm{~mm}$ \\
\hline & G6-G30-E50 & & & $50 \mathrm{~mm}$ \\
\hline & G6-G30-F & & & Flexural \\
\hline
\end{tabular}


Table 2. Mechanical properties of steel and GFRP bars

\begin{tabular}{|c|c|c|c|c|c|}
\hline Bar size & $\begin{array}{c}\text { Nominal } \\
\text { diameter } \\
(\mathrm{mm})\end{array}$ & $\begin{array}{c}\text { Area } \\
\left(\mathrm{mm}^{2}\right)\end{array}$ & $\begin{array}{c}\text { Tensile strength } \\
(\mathrm{MPa})\end{array}$ & $\begin{array}{c}\text { Elastic } \\
\text { modulus } \\
(\mathrm{GPa})\end{array}$ & $\begin{array}{c}\text { Strain corresponding } \\
\text { to tensile strength } \\
(\mathrm{mm} / \mathrm{mm})\end{array}$ \\
\hline $\mathrm{N} 12$ & 12 & 113 & $600^{\mathrm{b}}$ & 200 & 0.0030 \\
\hline $\mathrm{R} 10$ & 10 & 78.5 & $400^{\mathrm{b}}$ & 190 & 0.0021 \\
\hline$\# 4$ & $14.6^{\mathrm{a}}$ & $168^{\mathrm{a}}$ & $1200^{\mathrm{c}, \mathrm{d}}$ & $50^{\mathrm{d}}$ & 0.0240 \\
\hline$\# 3$ & $11^{\mathrm{a}}$ & $95^{\mathrm{a}}$ & $1275^{\mathrm{c}, \mathrm{d}}$ & $57^{\mathrm{d}}$ & 0.0224 \\
\hline
\end{tabular}

${ }^{\mathrm{a}}$ Determined from immersion test

${ }^{\mathrm{b}}$ Yield tensile strength

${ }^{\mathrm{c}}$ Ultimate tensile strength

${ }^{\mathrm{d}}$ Calculated based on the cross-sectional areas obtained from immersion test 
Table 3. Experimental results of the tested column specimens under concentric loads

\begin{tabular}{|c|c|c|c|c|c|c|c|}
\hline \multirow{4}{*}{ Specimen } & \multicolumn{2}{|c|}{ First peak } & \multicolumn{3}{c|}{ Second peak } & \multicolumn{2}{c|}{ Ductility } \\
\cline { 2 - 8 } & Axial & $P_{\text {bar }}{ }^{\mathrm{a}}$ & Axial & $P_{\text {bar }}{ }^{\mathrm{a}}$ & $f_{c c} \mathrm{~b}^{\mathrm{b}}$ & $I_{5}$ & $I_{10}$ \\
& $\mathrm{load}$ & $(\mathrm{kN})$ & $\mathrm{load}$ & $(\mathrm{kN})$ & $(\mathrm{MPa})$ & & \\
\hline S6-S60-C & 1528 & 407 & - & - & - & 4.8 & 8.7 \\
\hline G6-G60-C & 1220 & 163 & 1425 & 307 & 55.6 & 5.0 & 9.0 \\
\hline G6-G30-C & 1309 & 148 & 2041 & 494 & 76.9 & 5.1 & 11.6 \\
\hline
\end{tabular}

${ }^{\mathrm{a}} P_{\text {bar }}=\varepsilon_{\text {bar }} E_{\text {bar }} A_{\text {bar }}$

${ }^{\mathrm{b}}$ Calculated using Eq. (5) 
Table 4. Experimental results of the tested column specimens under eccentric loads

\begin{tabular}{|c|c|c|c|c|c|c|c|c|}
\hline \multirow{2}{*}{ Specimen } & \multicolumn{3}{|c|}{ First peak } & \multicolumn{3}{c|}{ Second peak } & \multicolumn{2}{c|}{ Ductility } \\
\cline { 2 - 10 } & Axial & Lateral & Bending & Axial & Lateral & Bending & & \\
& load & deformation & moment & load & deformation & moment & $I_{5}$ & $I_{10}$ \\
& $(\mathrm{kN})$ & $(\mathrm{mm})$ & $(\mathrm{kN.m})$ & $(\mathrm{kN})$ & $(\mathrm{mm})$ & $(\mathrm{kN} . \mathrm{m})$ & & \\
\hline S6-S60-E25 & 895 & 2.4 & 24.5 & - & - & - & 4.7 & 8.1 \\
\hline G6-G60-E25 & 781 & 2.5 & 21.5 & 751 & 11 & 27.0 & 4.8 & 8.6 \\
\hline G6-G30-E25 & 767 & 2.8 & 21.3 & 1003 & 19 & 44.1 & 5.5 & 9.2 \\
\hline S6-S60-E50 & 594 & 3.2 & 31.6 & - & - & - & 4.6 & 5.4 \\
\hline G6-G60-E50 & 494 & 3.4 & 26.4 & 459 & 15 & 29.8 & 4.7 & 5.8 \\
\hline G6-G30-E50 & 479 & 3.7 & 25.7 & 592 & 22 & 42.6 & 5.5 & 9.1 \\
\hline
\end{tabular}


Table 5. Experimental results of the tested beam specimens

\begin{tabular}{|c|c|c|c|c|c|c|}
\hline & \multicolumn{3}{|c|}{ First peak } & \multicolumn{3}{c|}{ Second peak } \\
\cline { 2 - 7 } Specimen & Load & Mid-span & Bending & Load & Mid-span & Bending \\
& $(\mathrm{kN})$ & deflection & moment & $(\mathrm{kN})$ & $(\mathrm{mm})$ & (kN.m) \\
& & $(\mathrm{mm})$ & $(\mathrm{kN} . \mathrm{m})$ & & - & - \\
\hline S6-S60-F & 344 & 6.5 & 40.1 & - & 17.5 & 31.3 \\
\hline G6-G60-F & 247 & 9.4 & 28.8 & 268 & 29.9 & 52.7 \\
\hline G6-G30-F & 242 & 8.1 & 28.2 & 452 & & \\
\hline
\end{tabular}




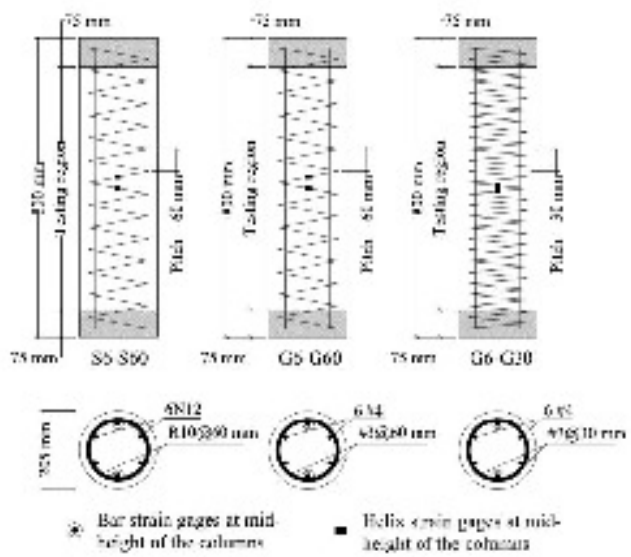

Fig. 1. Reinforcement details and dimensions of the specimens 


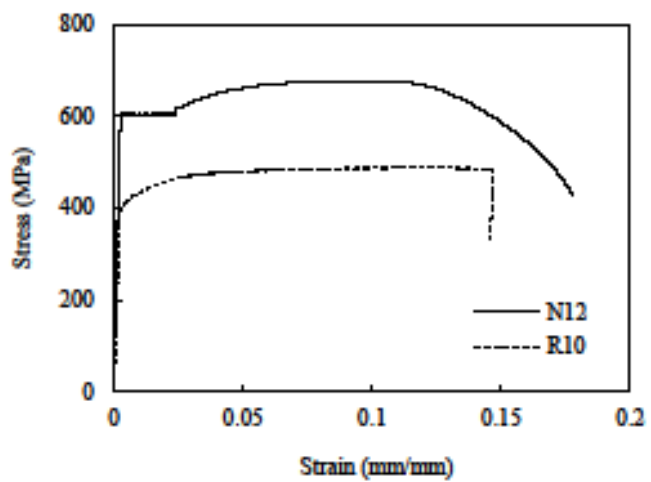

Fig. 2. Stress-strain behavior of steel bars 


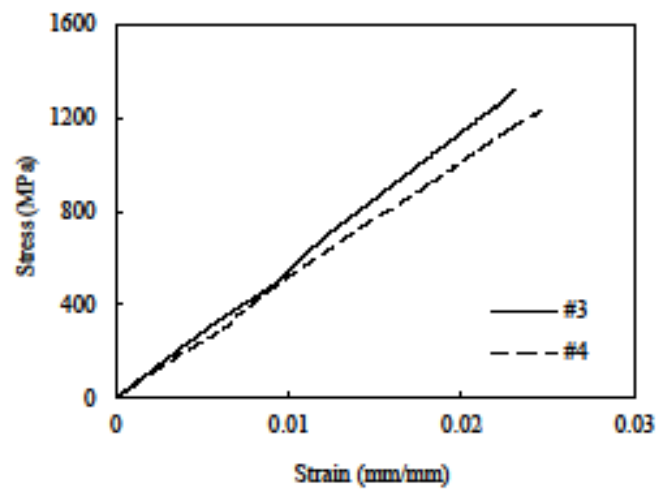

Fig. 3. Stress-strain behavior of GFRP bars 


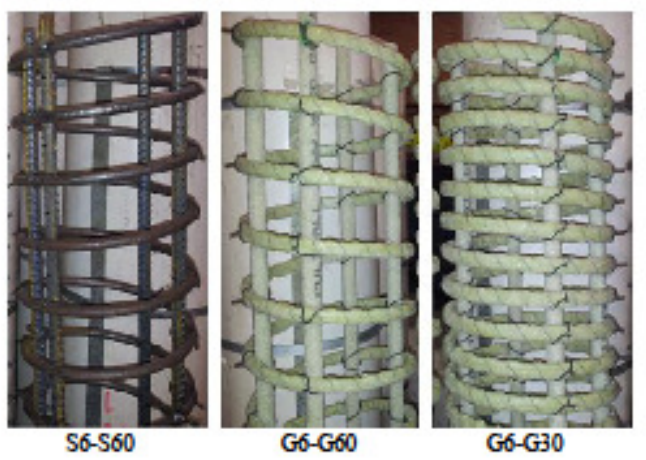

Fig. 4. Reinforcement cages

Page 38 of 52 

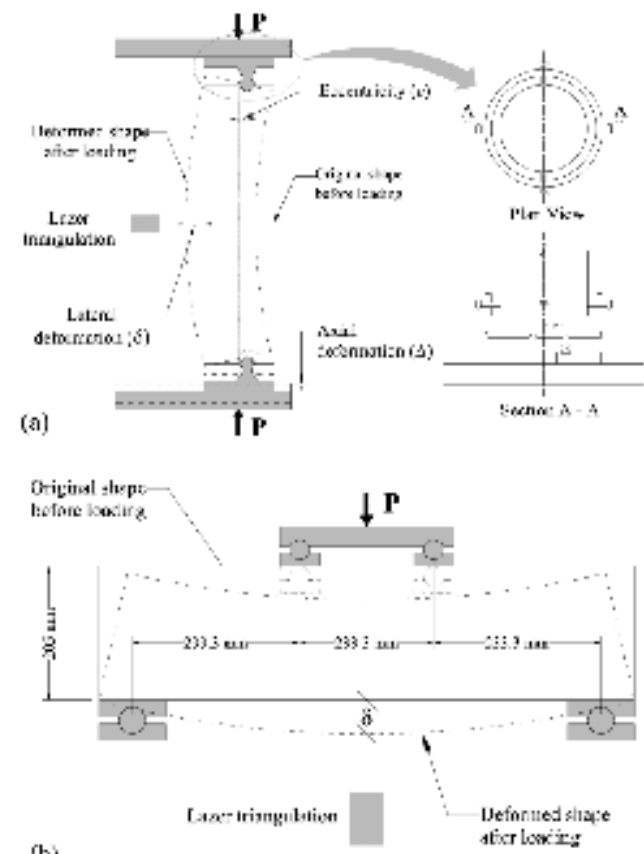

Fig. 5. Testing of specimens: (a) columns under eccentric load; and (b) beams under flexural load 


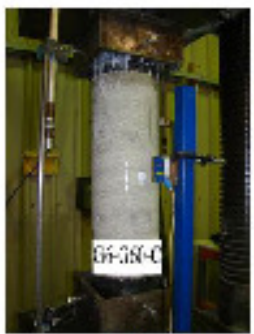

(a)

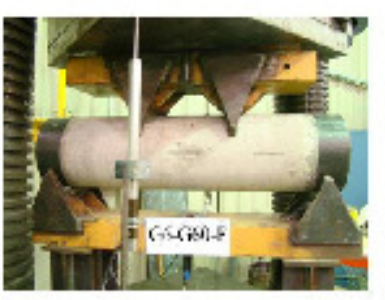

(b)

Fig. 6. Typical testing set up of the tested specimens:

(a) Column specimen; and (b) Beam specimen 

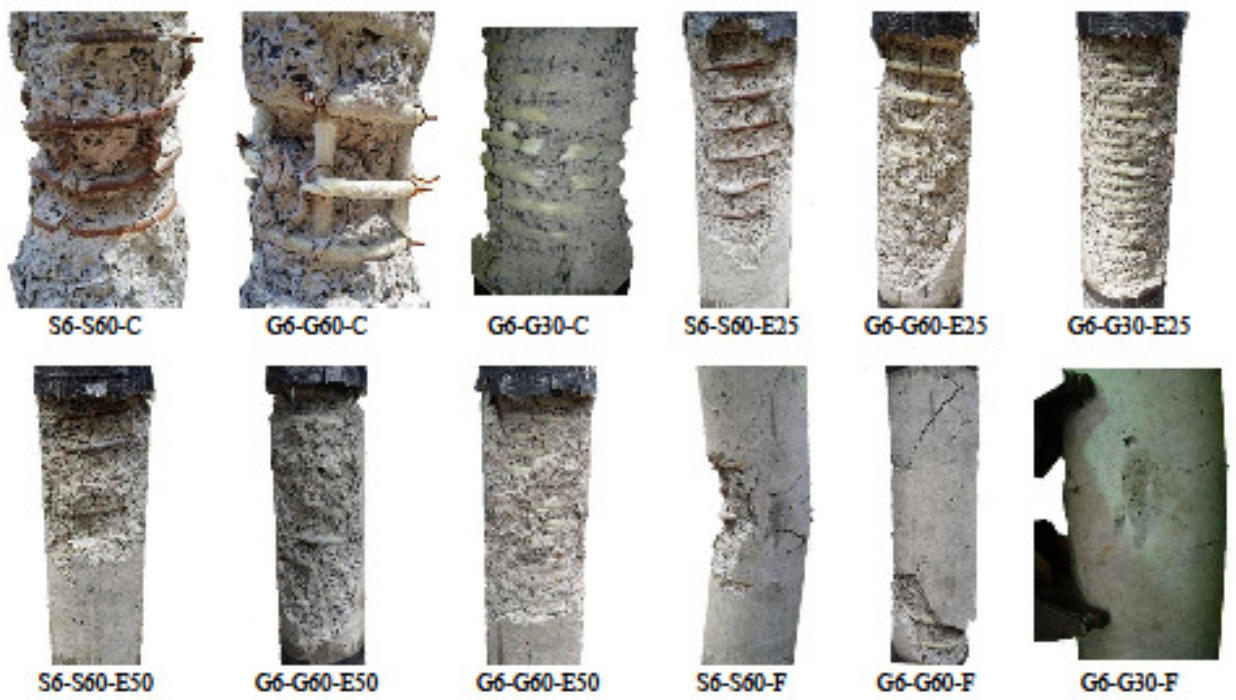

Fig. 7. Failure modes of the tested specimens 


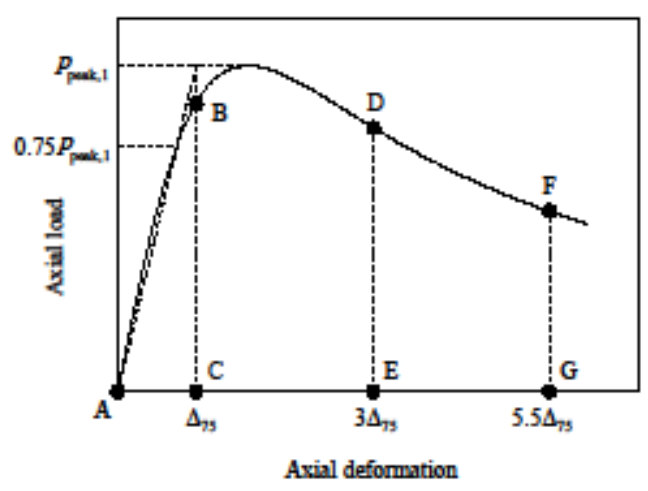

Fig. 8. Ductility measurement for the column specimens 


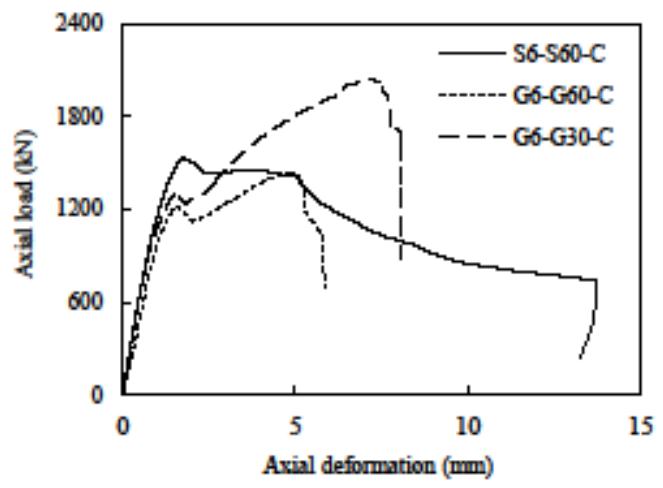

Fig. 9. Axial load-axial deformation behavior of column specimens tested under concentric loads 


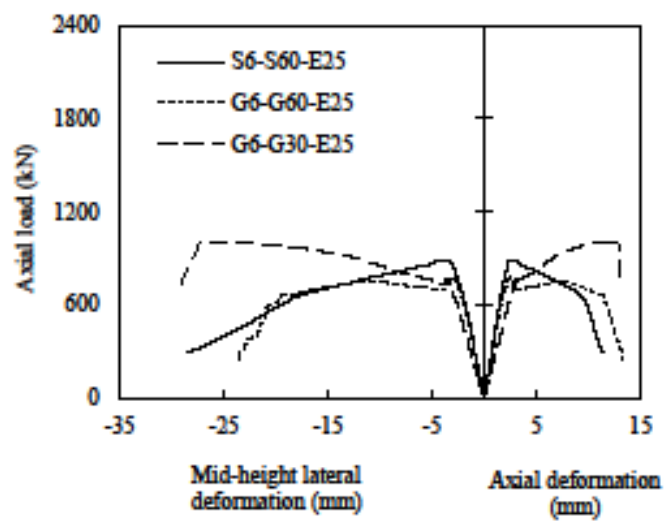

Fig. 10. Axial load-deformation behavior of column specimens tested under $25 \mathrm{~mm}$ eccentricity 


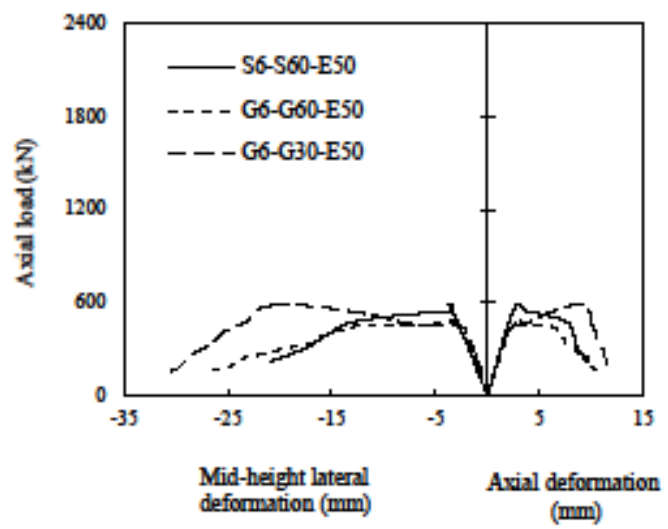

Fig. 11. Axial load-deformation behavior of column specimens tested under $50 \mathrm{~mm}$ eccentricity 


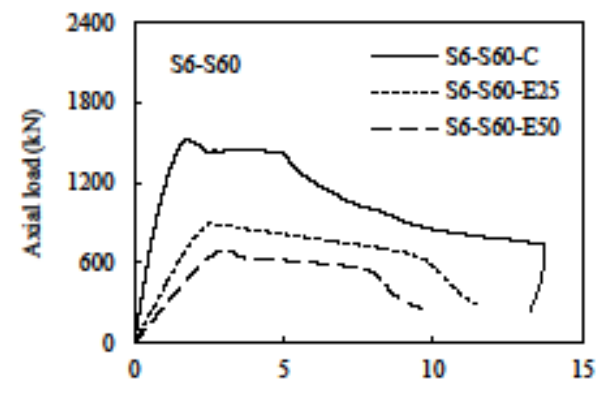

(a) Axial deformation (mm)

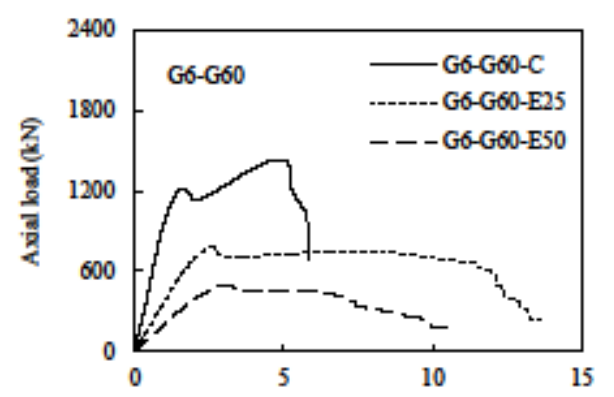

(b)

Axial deformation (mm)

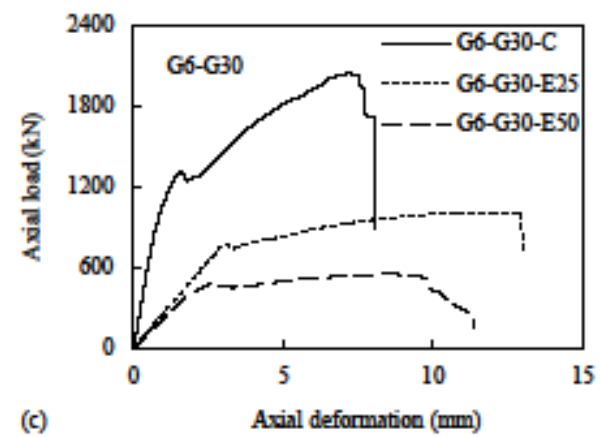

Fig. 12. Axial load-axial deformation behavior of column specimens tested under eccentric axial load: (a) S6-S60; (b) G6-G60; and (c) G6-G30 


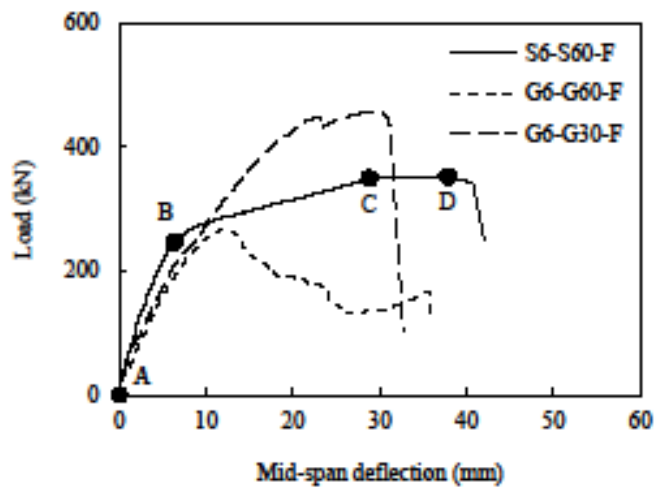

Fig. 13. Load-deflection behavior of beam specimens tested under flexural loads 

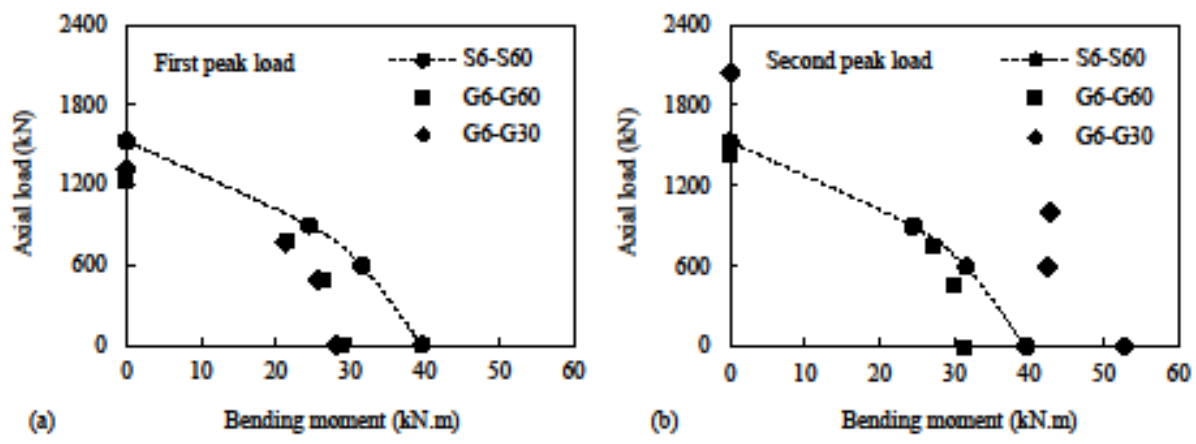

Fig. 14. Experimental peak axial load-bending moment diagram of the tested specimens: (a) First peak load; and (b) Second peak load 


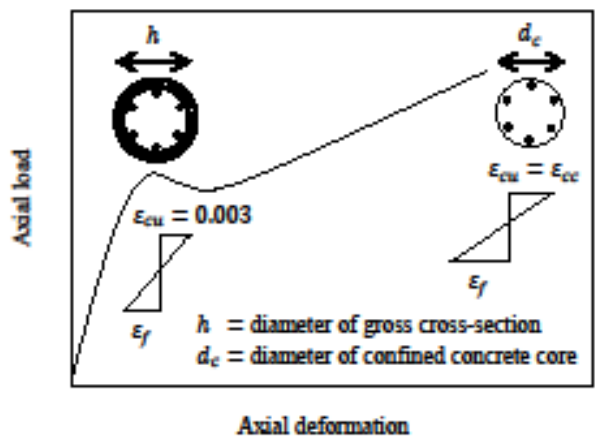

Fig. 15. Typical axial load-axial deformation behavior of GFRP-RC column specimens 


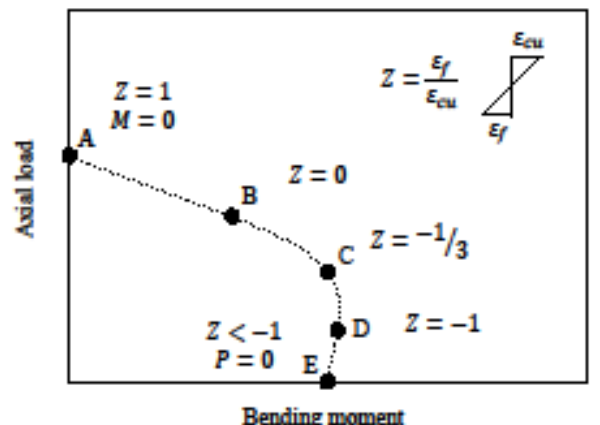

Fig. 16. Drawing of analytical peak axial load-bending moment diagrams 

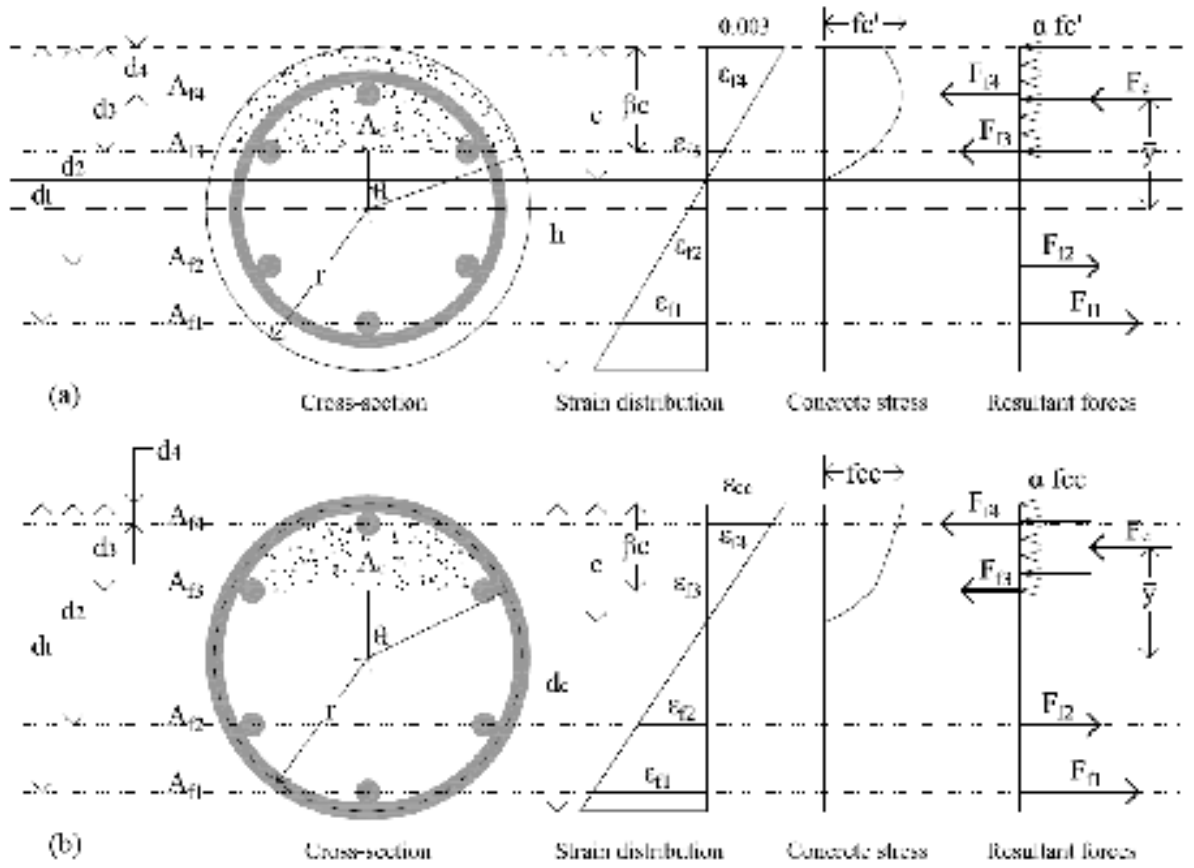

Fig. 17. Stress and strain profile of GFRP-RC cross-section: (a) First peak load; and (b)

Second peak load 

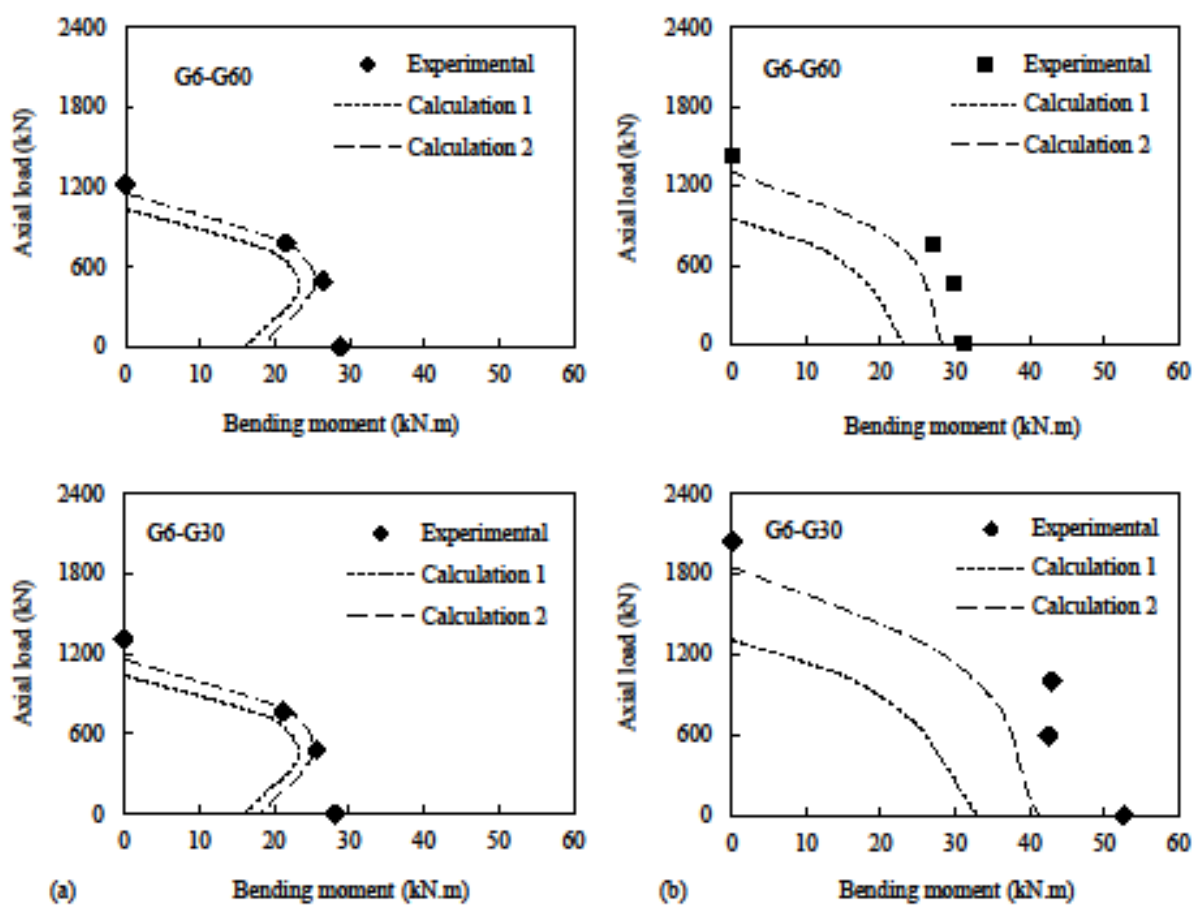

Fig. 18. Experimental and calculated peak axial load-bending moment diagrams: (a) First peak load; and (b) Second peak load

Note: Calculation 1: contribution of the GFRP bars was ignored in compression, and Calculation 2: contribution of the GFRP bars was taken into account in compression 